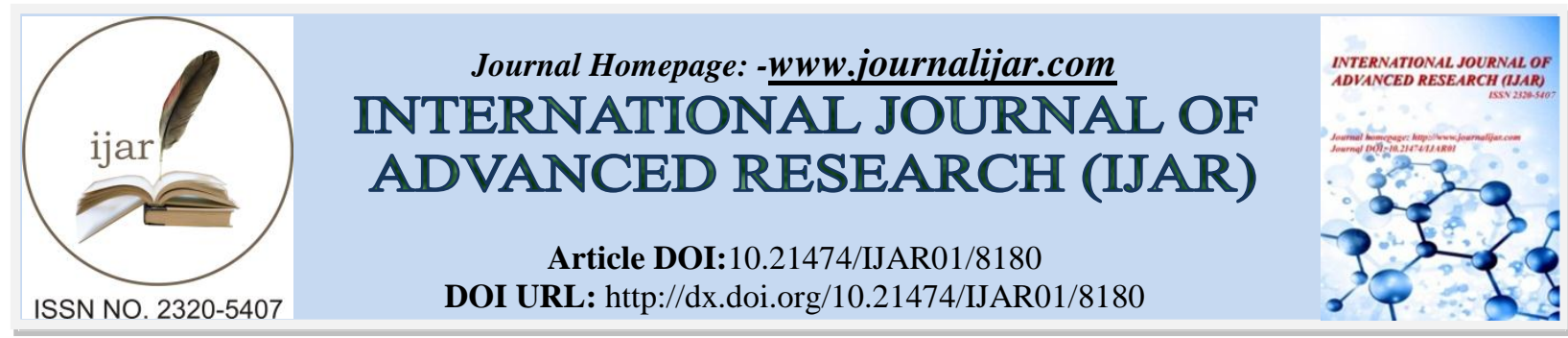

RESEARCH ARTICLE

\title{
EVALUATION OF STUDENTS SOURCES OF FINANCING HIGHER EDUCATION IN GHANA: A SURVEY OF TERTIARY INSTITUTIONS IN THE UPPER WEST REGION.
}

\author{
Abdul Moomen Pantah ${ }^{1}$ and Job Asante ${ }^{2}$. \\ 1. School of Business and Law, University for Development Studies, Wa Campus, Ghana. \\ 2. University for Development Studies, Wa Campus, Ghana.
}

\section{Manuscript Info}

Manuscript History

Received: 10 October 2018

Final Accepted: 12 November 2018

Published: December 2018

\begin{abstract}
Higher education is necessary for achieving the economic transformation of developing countries through human capital development. As a result, the government of Ghana has taken steps to finance tertiary level education in Ghana through a cost-sharing mechanism. However, poor students in deprived regions of Ghana still find it difficult in meeting the financial requirements of higher education. The objectives of this study are to: identify the sources of finance to students in higher education institutions, analyze the effectiveness of the sources of finance and the challenges students encounter in financing higher education. Primary data were collected from 153 students from the University for Development Studies and the Wa Polytechnic in the Upper West Region of Ghana. The data were collected using a questionnaire and analyzed using descriptive and chisquare statistics. It was discovered that students' main sources of financing their education include self-financing, single or both parents, relatives and scholarships. The effectiveness of these sources is mixed; implying that students have challenges relying exclusively on these sources. The main challenges identified include late payment of school fees, inability to meet basic needs in schools such as accommodation, food and study materials. The study concludes that students in the study institutions are vulnerable to higher education expenditures. It is recommended for the government through the GETFund to increase investment in higher educational institutions in the Upper West Region in the areas of infrastructure and scholarships to vulnerable students in the region.
\end{abstract}

Copy Right, IJAR, 2018,. All rights reserved.

\section{Introduction:-}

Sustainable growth in Africa is contingent on the capacity of states to diversify their economies and thus train human capital that will help to carry out and support this transformation. Higher education institutions in SubSaharan Africa can play this critical role in producing workers with the skills to assimilate technology and make effective decisions that will help the industry to diversify into a broader range of products (World Bank, 2010). To achieve the requisite economic transformation through human capital development, the government should consider it a priority to make higher education accessible to people (Oketch, 2016). Similarly, the role of higher education in economic transformation has been considered by those who advocate publicly funded higher education, as they are

Corresponding Author:-Abdul MoomenPantah.

Address:-School of Business and Law, University for Development Studies, Wa Campus, Ghana. 
conceived to convey the message of the greater good of higher education to society (Oketch, 2016). However, funding higher education has become increasingly difficult in the years ahead.

Currently, tertiary education development is unsustainable because resources per student are dwindling and the quality of education is affected. These issues are particularly pressing in times of global financial crisis, when available resources for tertiary education tend to diminish (World Bank, 2010). Tertiary education in public institutions in most African countries was almost entirely financed by public funds until the advent of the policy of cost sharing, which saw the implementation of user fees for all students undertaking a tertiary study (Oketch, 2016; Samuel et al., 2012). The reasons for this cost sharing are multifarious. For instance, Oketch, (2016) explained in his works that there has been unprecedented expansion in higher education since that sector was liberalized around the mid-1990s. According to him, enrolment in tertiary education grew faster in sub-Saharan Africa than any other region over the last four decades. This becomes a challenge to the sustainable financing of higher education (World Bank, 2010).

Moreover, it is very likely that in the near future the political and economic circumstances will lead to significant increases in higher education tuition charges (Chapman \& Sinning, 2011). Initially, there were protests when tuition fees were introduced in the 1990s in countries such as Kenya, Ghana, and Uganda (Oketch, 2016). Some of the arguments were that the majorityof students and parents were poor and could not afford to pay (Samuel et al., 2012). But today payment of fees has somewhat become increasingly accepted as a prerequisite for access to higher education and to redress underfunding amidst greater demand. As a result, Africa has maintained its public investment in higher education, allocating approximately 0.78 percent of its gross domestic product (GDP) and around 20 percent of its current public expenditure to this sector (World Bank, 2010). All public universities in East Africa, notably Kenya and Uganda, and in West Africa, notably Ghana, now run what is called "dual-track model", whereby a small number of students are enrolled on state funding and another group, usually twice or more the number on state funding, are enrolled to pay the full economic cost on their own (Oketch, 2016). In Ghana, students who qualified but did not meet the competitive admission cut-off point requirements are offered a fee-paying track option (Atuahene, 2009).

\section{Problem statement}

User fees in higher educational institutions have come in the form of meeting the full economic cost through what is referred to as cost-sharing whereby students meet the partial cost of their university education while the government pays for the rest (Oketch, 2016). Although the practice differs substantially between countries, higher education is often the one subsector in which there is little cost sharing, with governments financing all, or almost all, costs. This is particularly true of government-owned national universities (Asian Development Bank, 2009). The easiest reforms are the introduction of small administrative charges such as application, registration, and examination fees. While these meet relatively little resistance, they generate little income; and are, however, a first step in the direction of establishing a culture of cost sharing (Asian Development Bank, 2009). The new trend of applying cost-sharing concept has been widely accepted and applied in developed and developing countries.

In Ghana, until 1999, higher education was financed by the state. The introduction of cost-sharing policies have not only been politicized and attacked, but also created severe inequalities making higher education the preserve of the socially privileged (Atuahene, 2009). Undoubtedly, cost-sharing generates additional income for higher education institutions and relieves pressure on budgets but it raises the issue of capacity to pay (Okae-Adjei, 2012). Reports are that students face the issue of inadequate funding in their education and that result in problems which affect their concentration while studying (Samuel et al., 2012). Ally (2015) argues that there is no proper mechanism to protect poor students from dropping out of compulsory educational levels. The Upper West Region is one of the poorest regions in Ghana (Ghana Statistical Service, 2008) but has now attracted higher educational institutions. As these institutions have attracted students from households of high-income earners, yet a significant number of them constitute those from poor households. The question often raised is what happens to poor populations who cannot afford the cost of funding their education? What sources do student in higher education institutions rely on to finance their education? How effective are these sources of financing higher education? Do students face challenges in financing their educational needs?

\section{Research objectives}

The main objective of the study is to evaluate the sources from which students in higher education institutions in the Upper West Region finance their education. The specific objectives include: 
1. To identify the sources of finance to students in higher education institutions;

2. To analyze the effectiveness of sources of finance to students in higher education institutions;

3. To analyze the challenges students in higher education institutions face in financing their education.

\section{Literature Review}

Education is an investment, and like all investments, it creates costs in the present but delivers benefits in the future. While students are in school, expenses include both direct costs (tuition, books) and opportunity costs (Dynarski, 2014). According to MohdRamli and Mohamad (2013), the challenges of public funding of higher education in the current globalized and uncertain economic conditions require the adoption of suitable and appropriate financing mechanisms for the sustenance of the sector. To pay the current costs of their education, students need liquidity (Dynarski, 2014). Some of the ways by which the poor can be targeted include income-tested grants; giving money to universities to support scholarships for students from poor backgrounds; and incentives that promote aspiration for university education among the most underrepresented population groups. Recently, due to different funding models, things have improved (Oketch, 2016).

Many researchers, policymakers, and economists have advocated state funding of higher education. As in the case of Ghana, cognizant of these quagmires, and realizing the importance of higher education to national development, Parliament passed a bill that established the Ghana Education Trust Fund (GETFund Act 581) in 2000, which levies a 2.5\% Value Added Tax (VAT) on goods and services to supplement government budgetary allocations to education (Samuel et al., 2012; Atuahene, 2009). The purpose is to provide financial resources to support all educational institutions and offer financial assistance to genuinely needy and academically talented students. Atuahene (2009) then notice a tremendous contribution of the GETFund towards higher education development in Ghana. According to him, the Ghana Education Trust Fund supports needy and academically promising students to have access to secondary and tertiary education. The universities together with the National Council for Tertiary Education have developed a detailed form that will solicit information about needy students, and hence a consideration for the scholarship award.

Evidence from Samueil et al. (2012), Sanyal and Martin (2006), Indome (2013), Debrah (2008) and Oketch (2016) also show that some of the ways by which students finance their education are through social networking. For example, Samuel et al. (2012) conducted a study in Ghana on attitudes towards tuition fees payment in tertiary institutions. They reported that some sources of funding students' education are remittances from parents, friends and relatives. Parents or their substitute bear part of the cost of higher education through the payment of tuition and living cost. According to Sanyal and Martin (2006) parents do so from their current income, past savings, or loans to be paid from their future earnings. Indome (2013), added that the main sources of funding for students are parental support, personal savings/investment, siblings and relative support and the Student Loan Trust Fund. Debrah (2008) studied University of Ghana students and revealed that most of the students have parents in the middle-income class and can afford to pay for the cost of their wards education. He also maintains that students who have not had this privilege with their parents have to sell personal property to finance their education or junior siblings sacrificing their needs to fulfill the educational needs of adult ones. The case for development, notwithstanding, higher education the world over, in one way or the other, is paid for either by students or their families (Oketch, 2016). Samuel et al. (2012) also observed that in Ghana some students resort to vacation employment for the payment of their user fees at higher educational institutions. Dente and Pirarino (2014) indicated that social objective is a goal to increase access to higher education for poor students.

Governments across the world provide student loans, allowing students to borrow against the lifetime welfare gains created by a college education (Okae-Adjei, 2012; Ally, 2015; Dynarski, 2014). As important a factor as tuition and room and board are in determining student debt, the location of the university matters considerably. At universities in more urban areas, students borrow larger amounts for their education (Craig \& Raisanen, 2014). It is argued that such loans offer the freedom for poor students who meet university entry requirement to go to universities which are high cost or highly selective as they will not ex-ante be put off by unaffordable means to university, thus demotivating them to put in the extra effort required to meet the admission criteria for such selective institutions (Oketch, 2016). Two possibilities currently used internationally are mortgage-type and income contingent loans (Chapman \& Sinning, 2011). While borrowing has risen over time in the US, so too has the return to schooling (Dynarski, 2014). In Tanzania, Ally, (2015) and Nyahende (2013) found that the Students' Loan Scheme is effective in increasing access to Higher education as the number of students has risen significantly since the government 
established Higher Education Student Loan Scheme. Similarly, Wanyama et al. (2016) revealed that student loan scheme greatly contributes towards access to higher education at Makerere University in Uganda.

Over the years, funding for Higher or Tertiary Education in Ghana has seen several policy changes including the introduction of students' loan schemes and other innovative cost-sharing measures, driven by the need to reduce the cost burden on Government. This is in line with Okae-Adjei (2012) argument that the Students Loan Trust Fund (SLTF) was introduced by the government of Ghana to address the issue of cost-sharing in higher education. In analyzing the success and sustainability of the Student Loan Trust Fund (SLTF), Okae-Adjei (2012) found that the loan scheme appears quite successful as an alternative to funding higher education in Ghana and has the potential to become financially sustainable. In the year 2000 , Ghana initiated a sustainable funding policy which added $2.5 \%$ tax on the sale of goods and services to support tertiary education in the form of grants, scholarships and infrastructure (Republic of Ghana, 2017). Besides, various universities were also relying on their internally generated funds to meet some costs of their services to students. There were recent riots by university students in South Africa over proposed fees increase of about ten percent and this demonstrates the dilemma over the rising cost of higher education and who should pay for it (Oketch, 2016). The foregoing augments imply that there are institutional challenges associated with financing higher education in different places.

The Student Loan Scheme is one of the effective sources of financing higher education for students. However, its operations have been faced with challenges in different countries that have adopted it. In Zambia, Masaiti and Shen (2013) reported that one main challenge is government sponsoring students at subsidized rates that are not consummate with actual operational cost. This means that the future sustainability of the operation is not guaranteed. In Uganda, Wanyama (2016) observed that the elimination of loan schemes award to postgraduate students has limited access to higher education at the postgraduate level. This means that students pursuing higher education have considered the student loan scheme as a key source of financing. Kwasi-Agyeman (2015) found in Ghana that the government has taken a more active steering position when it comes to the allocation of resources and this has affected the tactical administrative position of the GETFund. Besides, Tonyi (2012) maintains that the amount of loan given to students in Ghana is inadequate

The empirical literature explains that students rely on different sources to finance the cost of higher education. However, the main sources of financing their education are personal savings, parents' savings, scholarships and Students Loan Scheme. While students from high income earning families rely on their parents to finance their education, those from poor homes use a multiplicity of these strategies to finance their education at higher educational institutions. Despite the fact that the literature discusses empirical findings from Ghana, there is little attention to financing higher education in relatively poorer regions such as the Upper West Region of Ghana. This study will therefore fill that void through an evaluation of the sources of financing higher education by students in the Upper West region.

\section{Methodology:- \\ Study area}

The University for Development Studies and the Wa Polytechnic are the largest public tertiary institutions in the Upper West Region that offer a variety of programmes. These unique features attract a pool of students into these institutions for the pursuance of academic programmes. Both the University for Development Studies and the Wa Polytechnic are located in the Wa Municipality of the Upper West region. Wa doubles as the Municipal and Regional capital of the Wa Municipality and Upper West Region respectively. Figure 1 represents the map of Wa Municipality with the locations of the study institutions. The University for Development Studies has two campuses (Old and Main) which are located at the western and southern part of the Municipality respectively. Wa Polytechnic is located at the southwestern part of the Municipality. Wa Polytechnic has a total student population of about 1,387 (Wa Polytechnic, 2014), whilst the University for Development Studies has a student population of about 8,344 pursuing accredited courses on Wa Campus (University for Development Studies, 2017). 


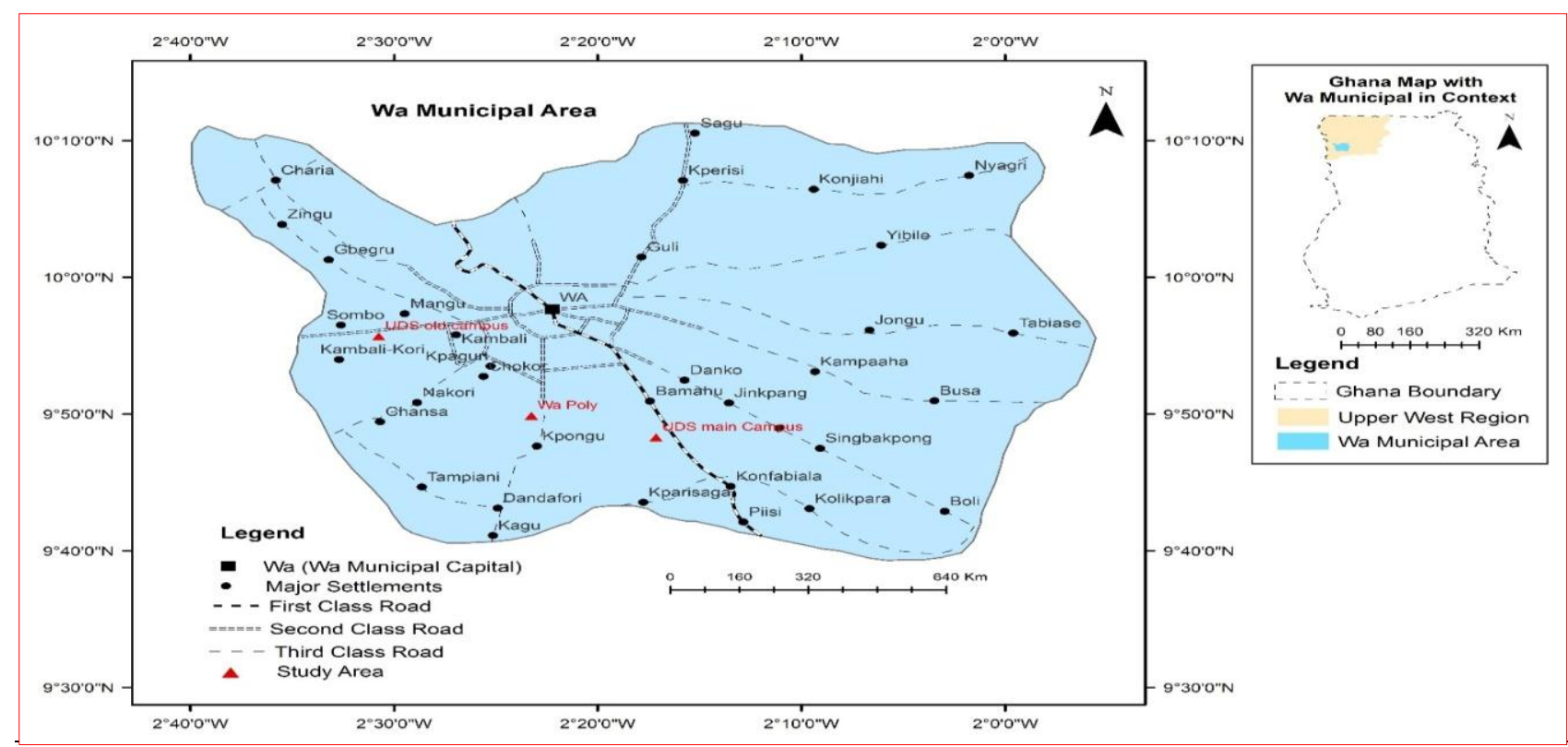

Figure 3.1:-Map of the study area

Source: Adapted from Azendongo (2016)

The Wa Polytechnic has different programmes leading to the award of Higher National Diploma (HND), Diploma in Business Studies (DBS) and other certificate courses. Besides, the University for Development Studies (Wa Campus) has three (3) Faculties: Faculty of Integrated Development Studies, Faculty of Planning and Land Management, and the School of Business and Law. These faculties run different programmes for both the undergraduate and graduate levels (University for Development Studies, 2017).

\section{Research Design}

A survey was conducted to collect primary data from students of Wa Campus, University for Development Studies and the Wa Polytechnic. Survey design usually produces a 'snapshot' of a population at a particular point in time (Kumar, 2011). A survey has several characteristics and several claimed attractions. Typically, it is used to scan a wide field of issues, populations, programmes etc. in order to measure or describe any generalized features (Cohen et al., 2007). The survey method can be used for descriptive, exploratory, or explanatory research. This method is best suited for studies that have individual people as the unit of analysis (Bhattacherjee, 2012). The relative strength of the survey method informs the choice of it for this study.

Besides, this is a descriptive study that aimed at describing the sources of finance to students at higher educational institutions. According to Best and Khan (1998) and Kumar (2011), the descriptive design is concerned with the conditions and relationships that exist, such as determining the nature of prevailing conditions, practices and ongoing processes or trends that are developed. This study therefore, describes the sources of funding and the relative effectiveness of students' financing of their higher education.

\section{Population and sampling}

The population of the study consist of undergraduate students of the two institutions. Statistics indicate that student enrolment of Wa Polytechnic is 1,387 (Wa Polytechnic, 2014) and that of the University for Development Studies, Wa campus is 8344 (University for Development Studies, 2017). The sample size for the students was estimated using a statistical procedure proposed by Miller and Browser (2003). The formula is given as:

$\mathrm{n}=\frac{N}{1+N(e)^{2}}$

Where $\mathrm{n}=$ sample size; $\mathrm{N}=$ sample frame and $\mathrm{e}=$ error or significance level. According to Ahuja (2001), an acceptable error level traditionally is up to \pm 0.05 or \pm 0.10 (i.e., 5 or 10 percentage point). In this study, $\mathrm{N}=8344$, e $=8 \%$.

Hence the estimated sample size for the study is 
$\mathrm{n}=\frac{8344}{1+8344(0.05)^{2}}=153$

The sample size was distributed proportionally to the students' population of the two institutions. Out of the 153 respondents, 79 were selected from students of the University for Development Studies and 74 were selected from the Wa Polytechnic.

The multi-stage sampling procedure was used to select the students from each institution. The stages involve the selection of faculties, departments and finally the selection of student; each using a simple random process.

\section{Data collection and analysis}

Only primary data were collected from the students through the use of a questionnaire. The data collected through the questionnaire produced quantitative data which were analyzed using descriptive and inferential statistics.

\section{Results And Discussion}

This section presents the results and discussion of the study. The results are presented and discussed under the background characteristics, students' sources of financing higher education, the effectiveness of sources of financing higher education among students, and the challenges associated with students' financing their higher education.

\section{Background characteristics of respondents}

The respondents of the study consist of both male and female students. The male students constitute $56.9 \%$ of the sample while the female students constitute $43.1 \%$. The students were found to have been pursuing different programmes such as physical sciences, social sciences, business, education, and Diploma in Business Studies (DBS). Among the programmes, the majority (54.2\%) of the students pursue business-related programmes followed by those in social sciences $(28.1 \%)$. The remaining programmes shown in Table 1 are pursued by less than $10 \%$ in each case. The respondents were also found to be in different levels of study. Majority of them (41.2\%) were found to be in level 200. Besides, 37.35 were in level 300, 11.1\% in level 400 and $10.5 \%$ found in level 100 . The ages of the students range from 24 to 42 as revealed by the minimum and maximum statistics in Table 1 . The mean age is 30.72 with a standard deviation of 5.45 .

Table 1:-Respondents' Background Characteristics

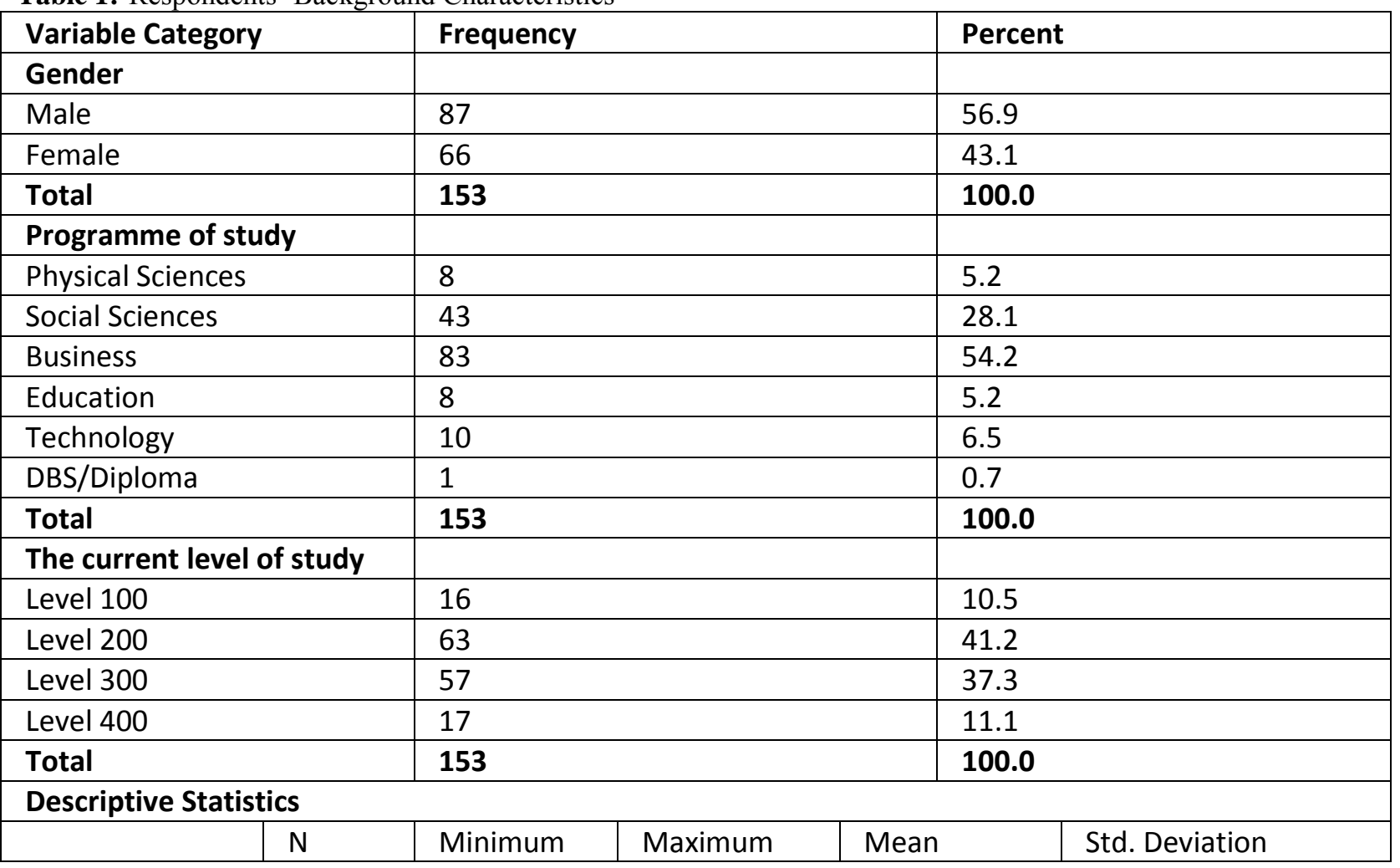




\begin{tabular}{|l|l|l|l|l|l|}
\hline Students' age & 153 & 24 & 42 & 30.72 & 5.450 \\
\hline
\end{tabular}

Source: Field Survey (2018)

The results on background characteristics of the respondents imply that the students have different background features and might have differences in financing their education. The estimated average age implies that the students are matured enough to take care of themselves and hence can find ways of financing their higher education.

\section{Sources of financing higher education}

Different sources of financing higher education among students were found in this study. It was discovered that the main sources are self-financing, financing by only the father or mother of the student or both, financing by a relative, guardian or through scholarship. Figure 1 shows that financing by both parents of the student dominates (34\%) over the other means. The results also show that self-financing is also important with $22 \%$ of the respondents financing their education by themselves. The less common among the sources is the use of scholarships which recorded $1 \%$ and guardian with $6 \%$.

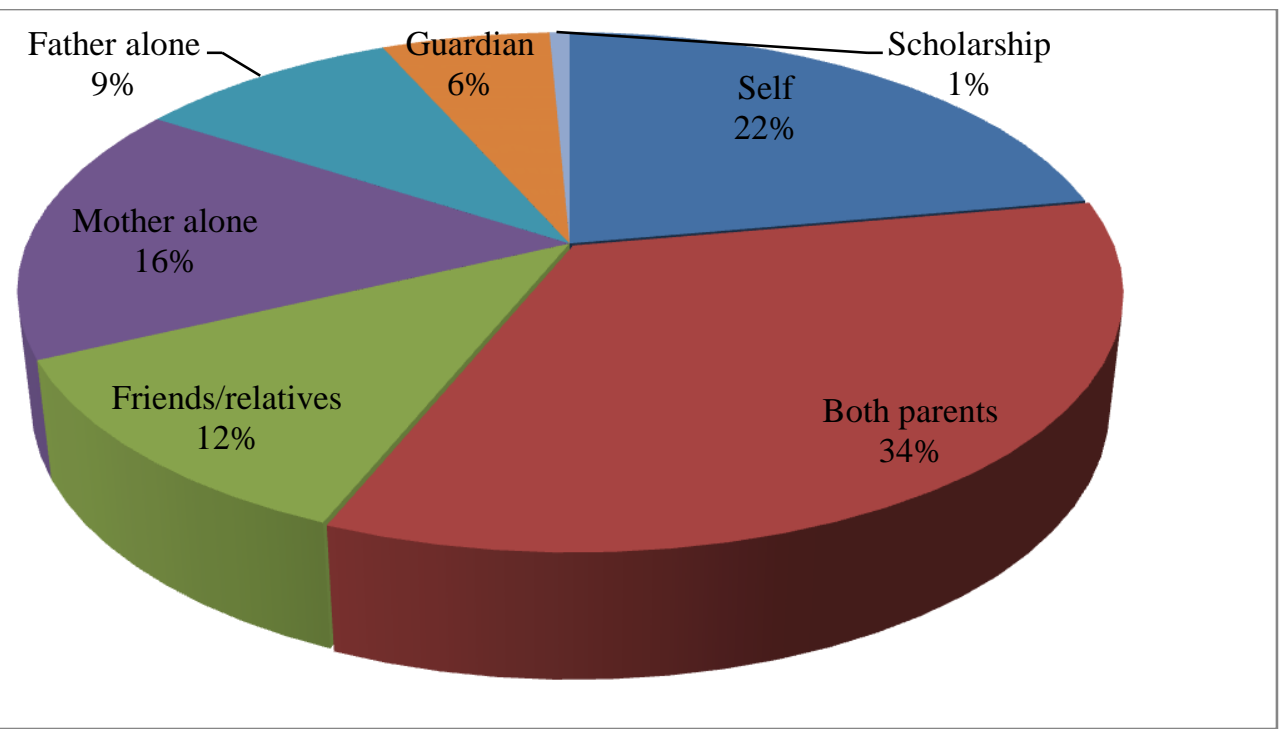

Source: Field Survey (2018)

Figure 2:-Sources of Financing Higher Education

The results indicate that parents are very active in financing their wards education since about $34 \%$ of the respondents rely on parents support to finance their education. This dominates because the cost is relatively high for one person to meet. Those who have a single parent financing their education means that one of their parents is not available or do not have the financial capability to meet the cost of higher education in Ghana. Besides, students rely on their own effort and sometimes the support of other relatives in financing their education. These findings agree with Samuel et al. (2012) that tertiary students in Ghana rely on remittances from parents, friend and relatives to pay their user fees. Indome's (2013) findings are also consistent with the results of this study. Indome (2013) reported that the main sources of funding for students are parental support, personal savings/investment, siblings and relative support and the Student Loan Trust Fund. However, the use of the Student Loan Trust Fund by students is not common in this study.

Further analysis was done to find out the independence of student gender on their source of financing education. The analysis was done using a chi-square test. From Table 2, a chi-square value of 11.32 was observed and this was found to be significant at $10 \%$. This means that the claim of independence of student gender on their sources of financing their education should be rejected. Therefore, the conclusion is that there is significant variation between male and female students' sources of financing their education. This conclusion is obvious in Table 2 since $73.5 \%$ and only $26.5 \%$ of female students finance their own education. Besides, more male students (68\%) have their mothers financing their education and more female students $(64.3 \%)$ have their fathers financing their education alone. 
Table 2:-Sources of Financing Higher Education by Gender

\begin{tabular}{|l|l|l|l|}
\hline \multirow{2}{*}{ Source of financing } & Gender of student & \multirow{2}{*}{ Total } \\
\cline { 2 - 3 } & Male & Female & \\
\hline Self & $25(73.5 \%)$ & $9(26.5 \%)$ & $34(100.0 \%)$ \\
\hline Both parents & $25(48.1 \%)$ & $27(51.9 \%)$ & $52(100.0 \%)$ \\
\hline Friends/relatives & $9(50.0 \%)$ & $9(50.0 \%)$ & $18(100.0 \%)$ \\
\hline Mother alone & $17(68.0 \%)$ & $8(32.0 \%)$ & $25(100.0 \%)$ \\
\hline Father alone & $5(35.7 \%)$ & $9(64.3 \%)$ & $14(100.0 \%)$ \\
\hline Guardian & $6(66.7 \%)$ & $3(33.3 \%)$ & $9(100.0 \%)$ \\
\hline Sponsor/benefactor & $0(0.0 \%)$ & $1(100.0 \%)$ & $1(100.0 \%)$ \\
\hline Total & $\mathbf{8 7 ( 5 6 . 9 \% )}$ & $\mathbf{6 6}(\mathbf{4 3 . 1 \% )}$ & $\mathbf{1 5 3 ( 1 0 0 . 0 \% )}$ \\
\hline $\mathrm{N}=153$, Pearson Chi-Square $=11.32, \mathrm{df}=6$, Asymp. Sig. (2-sided) $=0.079$ \\
\hline
\end{tabular}

Source: Field Survey (2018)

Similar chi-square analysis was done on the independence of student sources of finance on their current institution of study (The University for Development Studies or Wa Polytechnic). The results as shown in Table 3 recorded a chi-square value of 8.588 and this was found not to be significant even at $10 \%$. This means that there is not enough evidence to reject the claim of impendence of sources of finance on the institution of study. This finding therefore, implies that students' source of financing their education does not vary significantly by the institution of study. This means that students of the University for Development Studies and the Wa Polytechnic all rely on similar sources of financing their higher education.

Table 3:-Sources of Financing Higher Education Institution

\begin{tabular}{|l|l|l|l|}
\hline \multirow{2}{*}{ Source of financing } & \multicolumn{2}{|l|}{ Total } \\
\cline { 2 - 3 } & $\begin{array}{l}\text { University for Development } \\
\text { Studies }\end{array}$ & Wa Polytechnic & \\
\hline Self & $15(44.1 \%)$ & $19(55.9 \%)$ & $34(100 \%)$ \\
\hline Both parents & $32(61.5 \%)$ & $20(38.5 \%)$ & $52(100 \%)$ \\
\hline Friends/relatives & $6(33.3 \%)$ & $12(66.7 \%)$ & $18(100 \%)$ \\
\hline Mother alone & $14(56.0 \%)$ & $11(44.0 \%)$ & $25(100 \%)$ \\
\hline Father alone & $5(35.7 \%)$ & $9(64.3 \%)$ & $14(100 \%)$ \\
\hline Guardian & $6(66.7 \%)$ & $3(33.3 \%)$ & $9(100 \%)$ \\
\hline Scholarship & $1(100.0 \%)$ & $0(0.0 \%)$ & $1(100 \%)$ \\
\hline Total & $\mathbf{7 9 ( 5 1 . 6 \% )}$ & $\mathbf{7 4 ( 4 8 . 4 \% )}$ & $\mathbf{1 5 3 ( 1 0 0 \% )}$ \\
\hline $\mathrm{N}=153$, Pearson Chi-Square $=8.588, \mathrm{df}=6$, Asymp. Sig. (2-sided) $=0.198$ & \\
\hline
\end{tabular}

Source: Field Survey (2018)

Moreover, the results in Table 4 revealed that programmes of study do not influence students' sources of financing higher education. This was confirmed by a chi-square analysis which recorded a test value of 23.68 with a degree of freedom of 30 which was not significant at $10 \%$. This information suggests independence of programme of study on the source of finance. It was expected that student pursuing the physical science would have needed more financial resources to undertake practical work and hence attract external sources of finance different from those in the social sciences. This was however, not the case in the study area since all students irrespective of the programme of study rely on similar sources in financing their education.

Table 4:-Sources of Financing Higher Education by Programme of Study

\begin{tabular}{|l|l|l|l|l|l|l|l|}
\hline \begin{tabular}{l} 
Source of $\begin{array}{l}\text { Tocial } \\
\text { financing }\end{array}$ \\
\cline { 2 - 6 }
\end{tabular} & $\begin{array}{l}\text { Programme } \\
\text { I } \\
\text { Science } \\
\mathrm{s}\end{array}$ & $\begin{array}{l}\text { Sciences } \\
\text { Shica }\end{array}$ & $\begin{array}{l}\text { Educatio } \\
\mathrm{n}\end{array}$ & $\begin{array}{l}\text { Technolo } \\
\text { gy }\end{array}$ & $\begin{array}{l}\text { DBS/ } \\
\text { Diplom } \\
\text { a }\end{array}$ & \\
& & & & \\
\hline
\end{tabular}




\begin{tabular}{|l|l|l|l|l|l|l|l|}
\hline Self & $3(8.8 \%)$ & $8(23.5 \%)$ & $\begin{array}{l}20(58.8 \\
\%)\end{array}$ & $1(2.9 \%)$ & $2(5.9 \%)$ & $\begin{array}{l}0(0.0 \% \\
)\end{array}$ & $34(100 \%)$ \\
\hline Both parents & $3(5.8 \%)$ & $\begin{array}{l}20(38.5 \% \\
\text { ) }\end{array}$ & $\begin{array}{l}23(44.2 \\
\%)\end{array}$ & $2(3.8 \%)$ & $4(7.7 \%)$ & $\begin{array}{l}0(0.0 \% \\
)\end{array}$ & $52(100 \%)$ \\
\hline $\begin{array}{l}\text { Friends/relativ } \\
\text { es }\end{array}$ & $0(0.0 \%)$ & $4(22.2 \%)$ & $\begin{array}{l}13(72.2 \\
\%)\end{array}$ & $1(5.6 \%)$ & $0(0.0 \%)$ & $\begin{array}{l}0(0.0 \% \\
)\end{array}$ & $18(100 \%)$ \\
\hline Mother alone & $0(0.0 \%)$ & $4(16.0 \%)$ & $\begin{array}{l}15(60.0 \\
\%)\end{array}$ & $\begin{array}{l}3(12.0 \% \\
)\end{array}$ & $2(8.0 \%)$ & $\begin{array}{l}1(4.0 \% \\
)\end{array}$ & $25(100 \%)$ \\
\hline Father alone & $1(7.1 \%)$ & $3(21.4 \%)$ & $\begin{array}{l}7(50.0 \%) \\
1(7.1 \%)\end{array}$ & $2(14.3 \%)$ & $\begin{array}{l}0(0.0 \% \\
)\end{array}$ & $14(100 \%)$ \\
\hline Guardian & $\begin{array}{l}1(11.1 \\
\%)\end{array}$ & $4(44.4 \%)$ & $\begin{array}{l}4(44.4 \%) \\
0(0.0 \%)\end{array}$ & $0(0.0 \%)$ & $\begin{array}{l}0(0.0 \% \\
)\end{array}$ & $9(100 \%)$ \\
\hline Scholarship & $0(0.0 \%)$ & $0(0.0 \%)$ & $\begin{array}{l}1(100.0 \\
\%)\end{array}$ & $0(0.0 \%)$ & $0(0.0 \%)$ & $\begin{array}{l}0(0.0 \% \\
)\end{array}$ & $1(100 \%)$ \\
\hline
\end{tabular}

Source: Field Survey (2018)

\section{Effectiveness of sources of financing higher education}

The relative effectiveness of the sources students rely on for financing their higher education was an objective of the study. A four-point Likert scale of: very effective, effective, neutral, and not effective was used to measure the degree of effectiveness. Besides, a chi-square test of independence was applied to test the independence of the effectiveness of sources of finance on the different financing streams. From Table 5, a chi-square value of 25.1 was recorded and found not to be significant at $10 \%$. This means that the distribution of effectiveness is the same across categories of sources of finance. Among the respondents who are financing their own education majority considered it as an at least effective source of finance, while $14.7 \%$ maintain that it is very effective another $14.7 \%$ indicated that it is not effective with $29.4 \%$ maintaining a neutral position. Besides, the majority of those financing their education through both parents considered it as at least effective with only $15.4 \%$ maintaining that both parent financing is not effective. With the exception of Guardian and scholarship sources of financing, the respondents rated all the other categories as at least effective.

Table 5:-Effectiveness of Sources of Financing Higher Education

\begin{tabular}{|l|l|l|l|l|l|}
\hline \multirow{2}{*}{ Source of financing } & Effectiveness of financing & \multirow{2}{*}{ Total } \\
\cline { 2 - 5 } & Very effective & Effective & Neutral & $\begin{array}{l}\text { Not } \\
\text { effective }\end{array}$ & \\
\hline Self & $5(14.7 \%)$ & $14(41.2 \%)$ & $10(29.4 \%)$ & $5(14.7 \%)$ & $34(100.0 \%)$ \\
\hline Both parents & $10(19.2 \%)$ & $24(46.2 \%)$ & $10(19.2 \%)$ & $8(15.4 \%)$ & $52(100.0 \%)$ \\
\hline Friends/relatives & $4(22.2 \%)$ & $7(38.9 \%)$ & $3(16.7 \%)$ & $4(22.2 \%)$ & $18(100.0 \%)$ \\
\hline Mother alone & $7(28.0 \%)$ & $8(32.0 \%)$ & $7(28.0 \%)$ & $3(12.0 \%)$ & $25(100.0 \%)$ \\
\hline Father alone & $4(28.6 \%)$ & $3(21.4 \%)$ & $5(35.7 \%)$ & $2(14.3 \%)$ & $14(100.0 \%)$ \\
\hline Guardian & $0(0.0 \%)$ & $2(22.2 \%)$ & $7(77.8 \%)$ & $0(0.0 \%)$ & $9(100.0 \%)$ \\
\hline Scholarship & $0(0.0 \%)$ & $0(0.0 \%)$ & $0(0.0 \%)$ & $1(100.0 \%)$ & $1(100.0 \%)$ \\
\hline \multicolumn{2}{|l|l|}{$58(37.9 \%)$} & $42(27.5 \%)$ & $23(15.0 \%)$ & $153(100.0 \%)$ \\
\hline $\mathrm{N}=153$, Pearson Chi-Square $=25.10, \mathrm{df}=18$, Asymp. Sig. (2-sided)=0.122 \\
\hline
\end{tabular}

Source: Field Survey (2018)

However, the fact that some students rated some of the sources of finance as not effective or in neutral positions in their decision means that some students face challenges in relying on their available sources of finance. Despite the fact that they have some means of financing their education, the sources do not provide reliable means of meeting 
their expenditures of higher education. This implies that some students of higher academic institutions in the Upper West Region do not finance their education with convenience.

\section{Challenges associated with sources of financing higher education}

It was revealed from the study that 139 respondents who represent $90.8 \%$ maintain that they have challenges in financing their education. On the other hand, 14 respondents $(9.2 \%)$ do not have challenges in financing their education. Further analysis revealed that the degree of severity of the challenges is the same across the categories of sources of finance as suggested by the significance of chi-square test statistics. It was discovered that the chi-square value of 14.5 was not significant at $10 \%$ and this means that the independence of the sources on the degree of severity cannot be rejected. This conclusion is obvious from Table 6 since there are only slight differences in the proportion of respondents who considered their challenges are very severe and those considering them as moderate.

Table 6:-Severity of Financial Challenges

\begin{tabular}{lllll}
\hline \multirow{2}{*}{ Source of financing } & \multicolumn{2}{l}{ The degree of Financial Challenge } & \multirow{2}{*}{ Total } \\
\cline { 2 - 4 } & Very severe & Moderate & No challenge & \\
\hline Self & $14(41.2 \%)$ & $18(52.9 \%)$ & $2(5.9 \%)$ & $34(100.0 \%)$ \\
Both parents & $15(28.8 \%)$ & $33(63.5 \%)$ & $4(7.7 \%)$ & $52(100.0 \%)$ \\
Friends/relatives & $7(38.9 \%)$ & $8(44.4 \%)$ & $3(16.7 \%)$ & $18(100.0 \%)$ \\
Mother alone & $11(44.0 \%)$ & $10(40.0 \%)$ & $4(16.0 \%)$ & $25(100.0 \%)$ \\
Father alone & $7(50.0 \%)$ & $6(42.9 \%)$ & $1(7.1 \%)$ & $14(100.0 \%)$ \\
Guardian & $7(77.8 \%)$ & $2(22.2 \%)$ & $0(0.0 \%)$ & $9(100.0 \%)$ \\
Sponsor/benefactor & $1(100.0 \%)$ & $0(0.0 \%)$ & $0(0.0 \%)$ & $1(100.0 \%)$ \\
Total & $62(40.5 \%)$ & $77(50.3 \%)$ & $14(9.2 \%)$ & $153(100.0 \%)$ \\
\hline $\mathrm{N}=153$, Pearson & Chi-Square $=14.54, \mathrm{df}=12$, Asymp. Sig. (2-sided) $=0.267$ &
\end{tabular}

$\mathrm{N}=153$, Pearson Chi-Square $=14.54, \mathrm{df}=12$, Asymp. Sig. $(2$-sided $)=0.267$

Source: Field Survey (2018)

The respondents were therefore asked to cite the main challenges encountered in financing their higher education. The results were recorded as multiple responses as shown in Table 7. The main challenges cited include late payment of fees, regular borrowing in meeting educational expenditures, inability to buy study materials, inability to pay transport, inability to pay for accommodation, and studying with hunger because of lack of food. From the table the frequently mention challenge is their inability to buy study materials (84\%), next is regular borrowing (83.7\%) to be able to finance their education, and inability to pay for accommodation (78.4\%).

Table 7:-Specific Financial Challenges

\begin{tabular}{|l|l|l|}
\hline Challenge in financing education & Frequency & Percent \\
\hline Late payment of fees & 75 & 49.0 \\
\hline Regular borrowing & 128 & 83.7 \\
\hline Unable to buy study materials & 129 & 84.3 \\
\hline Unable to pay for transport & 98 & 64.1 \\
\hline Unable to pay for accommodation & 120 & 78.4 \\
\hline Studying with hunger & 112 & 73.2 \\
\hline
\end{tabular}

Source: Field Survey (2018) multiple responses were considered

The fact that some students have challenges with getting food to eat (hunger) and also lacking accommodation means that some of their basic needs have not been met. Besides, the habit of continuing borrowing to finance their education means that the students are indebted and may have serious troubles if their sources of funds do not improve. The results of this study are consistent with that of Debrah (2008) who maintained that students with parents in middle-income class can afford to finance their education but those from low-income class have to sell the property or take loans in order to keep their wards in school. This means that the financing of higher education is extremely difficult for both parents and students. Besides, the case of regular borrowing to finance education is not a relatively new concept. Craig and Raisanen (2014) found that students in America; a developed country, have to borrow large amounts of money for their education. 


\section{Conclusion And Recommendations}

The results of the study imply that students in higher educational institutions in the Upper West Region use different sources to finance their education. The sources of funding are however, independent and students can use multiple sources to finance their education. The results imply that the sources of funding are available but their access to formal means such as through government sponsorships are limited. The Student Loan Trust Fund has been initiated as a national strategy of financing higher education but its access has been limited among the students. This means that government interventions on financing higher education in Ghana has not yet granted students access because students are still relying on their own means. The effectiveness of available sources of funding to students is mixed. While some students consider their sources as very effective, others remain neutral on their stand and some also indicate that their sources of financing their education are not effective. This implies that students are facing financial challenges in meeting their educational expenditures. The various challenges encountered by students in meeting their financial needs means that students are vulnerable to expenditures of higher education institutions in the Upper West Region.

The study therefore provides some recommendations for students, management of higher educational institutions, and government. Students of higher educational institutions in the Upper West Region are advised to utilize the Students Loan Trust Fund as an opportunity in financing higher education in Ghana. This, if effectively utilized will reduce the financial vulnerability that is associated with their education. Besides, the school libraries are opportunities for students to source academic materials free of charge and their effective utilization will reduce the expenditures incurred in buying study materials. Management of higher education institutions should collaborate with major stakeholders to provide accommodation facilities to students at subsidized rates. This will reduce the expenditures incurred by students and liberate needy students from accommodation challenges. While recent governments' policy on free education up to the Senior High School Level should not compromise investment in Higher Education Institutions. Students of the University for Development Studies and the Wa Polytechnic are vulnerable to expenditures associated with their education and hence need a subsidy. Government agencies such as GETFund should consider this a priority and increase investment in higher education institutions in the Upper West Region in the areas of infrastructure and scholarships to vulnerable students in the region.

\section{References}

1. Ahuja, R. (2001)." Research Methods". Jaipur: Rawat Publications

2. Ally, A. M. (2015). Sustainability of Higher Education Students' Loan Scheme (HESLS) in Tanzania. European Journal of Business and Management. ISSN 2222-1905 (Paper) ISSN 2222-2839 (Online). 7 (9). www.iiste.org

3. Asian Development Bank (2009). Good Practice in Cost Sharing and Financing in Higher Education. ISBN 978-971-561-849-6. Publication Stock No. TIM090997.

4. Atuahene, F. (2009). Financing Higher Education through Value Added Tax: A Review of the Contribution of the Ghana Education Trust Fund (GETFund) in Fulfilment of the Objectives of Act 581.Council for the Development of Social Science Research in Africa 2009; JHEA/RESA. 7(3), pp. 29-60, (ISSN 0851-7762).

5. Azendongo, E. A. (2016). Sustaining Higher Education in Ghana: The Role of the Students Loan Scheme, Thesis Submitted to the University for Development Studies, Tamale.

6. Bhattacherjee, A. (2012)."Social Science Research: Principles, Methods, and Practices"'Textbooks Collection.Book 3. http://scholarcommons.usf.edu/oa_textbooks/3

7. Chapman, B. and Sinning, M. (2011). Student Loan Reforms for German Higher Education: Financing Tuition Fees. Ruhr Economic Papers 244, ISSN 1864-4872 (online), ISBN 978-3-

8. Cohen, L. Manion, L. and Morrison, K. (2007). Research Methods in Education (Sixth Ed). Routledge Taylor and Francis Group; London and New York.

9. Craig, J. D. and Raisanen, S. R. (2014): Institutional determinants of American undergraduate student debt, Journal of Higher Education Policy and Management, DOI: 10.1080/1360080X.2014.957892. http://dx.doi.org/10.1080/1360080X.2014.957892.

10. Debrah, D. (2008). Financing Higher Education. Challenges for Students at the University of Ghana. University of Oslo, Norway.

11. Dente, B. and Piraino, N. (2011) Models for determining the efficiency of student loans policies, Journal of Higher Education Policy and Management, 33:4, 375-386, DOI: 10.1080/1360080X.2011.585737. http://dx.doi.org/10.1080/1360080X.2011.585737. http://www.tandfonline.com/loi/cjhe20. 
12. Dynarski, S. (2014). An Economist's Perspective on Student Loans in the United States. ES Working Paper Series. East-West Center/Korean Development Institute Conference on a New Direction in Human Capital Policy.dynarski@umich.edu.

13. Ghana Statistical Service (2008). Ghana Living Standards Survey Reports of the Fifth Round (GLSS5), September, 2008.

14. Indome, J. O. (2013). Financial Challenges and Coping Strategies of Students of the University of Cape Coast.

15. Kumar, R.(2011).Research methodology. A step-by-step guide for Beginners, Sage Publication Ltd. Olivers Yard 55 city Road, ECIX ISP

16. Kwasi-Agyeman, F. (2015). Organizing Higher Education Funding In Ghana: The Case of Ghana Education Trust Fund (GETFund). The University of Oslo.

17. Masaiti, G. and Shen, H. (2013). Cost Sharing in Zambia's Public Universities: Prospects and Challenges. European Journal of Educational Research.Vol. 2(1), pp: 1-15, ISSN 2165-8714. http://www.eu-jer.com. DOI: 10.12973/eu-jer.2.1.1.

18. Miller R. L., and Brewer, J. D. (2003). A-Z of Social Research - Dictionary of Key Social Science, Sage Publications, London.

19. MohdRamli, A. \&Mohamad, M. O. (2013). An Overview of Public Funding for Higher Learning Education in Malaysia and the Prospect of Waqf Funding.

20. Nyahende, V. R. (2013). The Success of Students' Loans in Financing Higher Education in Tanzania. Higher Education Studies; Canadian Center of Science and Education. Vol. 3(3). ISSN 1925-4741 E-ISSN 1925475X.www.ccsenet.org/hes.

21. Okae-Adjei, S. (2012). Student Loans as an Alternative to Funding Higher Education in Ghana: An Analysis of the Students Loan Trust Fund. Interdisciplinary Journal of Contemporary Research in Business. Institute of Interdisciplinary Business Research.Vol. 4(6). ijcrb.webs.com.

22. Oketch, M. (2016). Financing higher education in sub-Saharan Africa: some reflections and implications for sustainable development. High Educ 72:525-539, DOI 10.1007/s10734-016-0044-6.

23. Samuel, Y. A., Ernest, K. \&Gyamfi, C. (2012). Attitudes towards Tuition Fees Payment in Tertiary Education: A Survey of Sunyani Polytechnic Marketing Students in Sunyani Ghana. International Review of Management and Marketing.2 (4), pp.231-240. ISSN: 2146-4405. www.econjournals.com.

24. Sanyal B. C. and Martin, M. (2006). Financing Higher Education: International Perspectives.Higher Education in the World.

25. Tonyi, M. Y. (2012). The Effectiveness of the Students Loan Trust Fund in Financing Higher Education in Ghana.

26. University for Development Studies (2017). Vice-Chancellor's Report, University for Development Studies, Tamale.

27. Wa Polytechnic (2014). Academic Facility User Fees: Registry, Wa.

28. Wanyama, M. O., Kyohairwe, S. B. \& Karyeija, G.K. (2016). Students' Loan Scheme and Access to Higher Education at Makerere University, Uganda. Journal of Public Administration and Development Alternatives. 1(1.1).

29. World Bank (2010). Financing Higher Education in Africa. The International Bank for Reconstruction and Development / The World Bank 1818 H Street NW, Washington DC 20433. www.worldbank.org. 